\title{
CAMBRIDGE UNIVERSITY NATURAL RADIOCARBON MEASUREMENTS VIII
}

\author{
H. GODWIN and V. R. SWITSUR \\ Cambridge University*
}

INTRODUCTION

The dates and activity measurements given below have been obtained during 1964 and 1965, and have been made with $\mathrm{CO}_{2}$ at $3 \mathrm{~atm}$ pressure in a proportional gas-counter as described in previous contributions from this laboratory. We have continued to concentrate chiefly upon research projects pursued in the University Sub-department of Quaternary Research.

We particularly wish to acknowledge the help of G. A. Sutton, Technical Assistant in the Radiocarbon Dating Laboratory and of M. A. Hall, Scientific Assistant. For most of the samples fractionation errors have been determined mass-spectrometrically by N. J. Shackleton, Senior Assistant in Research; these have been stated in the text and taken into account in calculating the presented data. The corrections have been made with respect to the Cambridge standard wood sample (1850). The values for fractionation are calculated to the P.D.B. standard.

\section{SAMPLE DESCRIPTIONS}

BRITISH ISLES

\section{A. Late Weichselian}

\section{Q-816. Redkirk Point, Dumfriesshire 1A}

$12,290=250$

Peat (Grid ref. 35/056680; 54 59' N Lat, $3^{\circ} 28^{\prime} \mathrm{W}$ Long), from the same locality as Q-637 and Q-815. Below the (estuarine) Carse Clay is a peat-bed dated $8135 \pm 150$ (Q-637), and below this grey sandy clays which at one point overlie a peat bed containing a boreal beetle fauna and dated 10,300 \pm 185 (Q-815). This soft detritus peat of bed $1 \mathrm{~A}$ lies ca. $4 \mathrm{ft}$ below the upper peat; it lenses out to the $\mathrm{E}$ and thickens to $\mathrm{W}$; like the lower peat Q-815 it rests on grey to pink sands over boulder-clay. Pollen analyses by R. Andrew have a strongly Late-Weichselian character with $\mathrm{Be}, \mathrm{Pi}, \mathrm{Sa}$ as the only arboreal pollen and abundant herbaceous pollen including Selaginella, Empetrum, Thalictrum and cf Saussurea alpina. Coll. W. W. Bishop, Uganda Museum, Kampala, 1962. $\delta \mathrm{C}^{13}-31.1 \%$. Comment: date confirms the pollen-analytic findings, and indicates an age greater than that of the lower peat at Q-815: it is understandable that on the irregular surface of the boulder clay on this coast there should be Late-glacial peat deposits of varying ages.

* Radiocarbon Dating Laboratory, 5 Salisbury Villas, Station Road, Cambridge, and University Sub-department of Quaternary Research, Botany School, Cambridge, England. 


\section{B. Post-glacial vegetational history}

\section{Q-682. Chat Moss, Lancashire, Site 114, 14-16 cm}

Peat (Grid ref. 959.694, 53० $27^{\prime} \mathrm{N}$ Lat, $2^{\circ} 27^{\prime} \mathrm{W}$ Long) from a site 200 yd from completed pollen-analytic sequence through the raised-bog. From a deep pit a monolith was recovered crossing a pronounced recurrence surface traceable throughout the bog and dated pollen-analytically to the onset of Zone VIII (Birks, 1963-4). Stratigraphy as follows: 0 to 7 $\mathrm{cm}$, unhumified Sphagnum cuspidatum pool peat with a little Cladium, Rhyncospora alba, Andromeda and Eriophorum angustifolium; 7 to 9 $\mathrm{cm}$, Eriophorum vaginatum; 9 to $14 \mathrm{~cm}$, unhumified Sphagnum humhock peat $(\mathrm{H}=4) ; 14$ to $20 \mathrm{~cm}$, moderately humified Sphagnum peat; 20-, highly humified Sphagnum peat $(\mathrm{H}=8)$.

Samples Q-682 and 683 bracket the main shift to increasing wetness and correspond to the onset of a pronounced forest clearance phase leading to a mainly pastoral economy. Coll. J. Birks, Sidney Sussex College, Cambridge, $1962 . \delta \mathrm{C}^{13}-28.4 \%$.

\section{Q-683. Chat Moss, Lancashire Site 11 a, 3-5 cm}

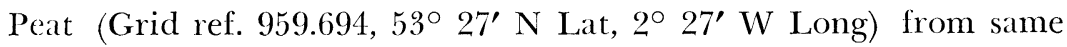
monolith as Q-682 above. Coll. J. Birks, 1962. $\delta \mathrm{C}^{13}-31.0 \%$. Comment: samples Q-682 and 683 that span the consistent major recurrence surface on Chat Moss yield dates consistent with one another and with the pollen analytic results. They confirm the conjecture (Birks, 1963/4) that the important forest clearance phase was referable to Late Bronze Age or Early Iron Age. The date is similar to that for the main flooding horizon in the raised bogs of the Somerset Levels (Cambridge I) and to that of the main recurrence surface in Tregaron bog, Cardiganshire (Q-388, 389: Cambridge II).

\section{Land-and Sealevel Changes}

Continuing the research of the Univ. Sub-dept. of Quaternary Research, Cambridge there are seven samples from the East Anglian Fenland basin and adjacent coast and a series from the south coast at Southampton all submitted by D. W. Churchill, and two further samples add to the serries from SW Scotland. These extend the coastal datings given in Cambridge, I, III, V, VI, VII.

\section{Welney Wash series, Norfolk}

D. M. Churchill carefully reinvestigated the stratigraphy of the former Romano-British river channel (the roddon) at Welney Wash $\left(52^{\circ}\right.$ $29^{\prime} \mathrm{N}$ Lat, $0^{\circ} 21^{\prime}$ E Long) at the site excavated by C. W. Phillips in 1935 (Phillips, 1936a, b). Two separate periods of Romano-British occupation were identified within the mineral deposits of the levée. These are shown by faunal and floristic remains to be at least partially marine in origin. They are continuous with the so-called 'upper silts' that occupy 
large parts of the seaward side of the Fenland basin, and like them overlie the so-called 'upper peat' which began to form ca. 2400 в.c. It has been unclear when marine transgression put an end to this peat formation, some radiocarbon dates e.g. Q-547 being as early as $1355 \pm 120$ в.c., and other e.g. Q-806 being as late as $325 \pm 100$ B.C. (Cambridge VII). To give more precision to the date of the onset of this transgression pits were dug to obtain samples Q-819, Q-820 for radiocarbon dating at the uneroded surface of the upper peat. The contamination by secondarily intruded Phragmites stems from above was investigated by the further samples Q-823 and Q-829. Coll. D. M. Churchill, University Sub-dept. of Quaternary Research, Cambridge, 1964.

\section{Q-819. Welney Wash, Norfolk, No. 4}

$1970 \pm 100$

20 B.c.

Peat from pit beside bore 8 at 110 to $120 \mathrm{~cm}$ from surface, the top inch of peat directly below ca. $+20 \mathrm{~cm}$ O.D., underlying without disconformity a thin Phragmites clay that is overlain by the (estuarine) silts of the roddon. $\delta \mathrm{C}^{13}-32.5 \%$. Comment: contamination by younger Phragmites rhizomes evident.

\section{Q-820. Welney Wash, Norfolk, No. 1}

$1940 \pm 130$

Peat from pit beside bore $14 \mathrm{ca} .80 \mathrm{~cm}$ from the surface, from the top of the upper peat at ca. $+40 \mathrm{~cm} \mathrm{O.D.,} \mathrm{where} \mathrm{it} \mathrm{directly} \mathrm{underlies} \mathrm{the}$ grey estuarine clay with Hydrobia and Cardium edule. $\delta \mathrm{C}^{13}-32.5 \%$. Comment: contamination by younger Phagmites rhizomes erident (see below, Q-823) .

\section{Q-823. Welney Wash, Norfolk, No. 2}

$1212 \pm 154$

Phragmites rhizomes mostly horizontal and not penetrated by rootlets, part of the sample from which Q-820 was taken, separated from the matrix and carefully washed. $\delta \mathrm{C}^{13}-33.6 \%$. Comment: the rhizomes are clearly younger than the peat into which they have intruded (see below, Q-829).

\section{Q-829. Welney W ash, Norfolk, No. 3}

Residues of the peat of Q-823 after removal of the Phragmites rhizomes were treated with $\mathrm{NaOH}$ to remove the soluble humic acid fraction that constitutes the bulk of the peat. The reprecipitated material was dated. $\delta \mathrm{C}^{13}-32.5 \%$.

Comment on Welney Wash series: Q-819 and 820 clearly give dates that are too young because of contamination by more recent Phragmites rhizomes (Q-823) though there is no trace of where these penetrated the overlying clay. Sample Q-829 is free from visible remains of Phragmites and gives a minimal age of 317 B.c. for the top of the peat bed, but it could still contain some alkali-soluble material derived from the contaminant material, but probably not so much as to equal the effect of 
visible Phragmites (i.e., $300 \mathrm{yr}$ ). Therefore adding a further 300 yr to that of the alkali-soluble fraction (Q-829) should give an approximate older limit for the age of the top of the upper peat, which therefore at Welney should lie between ca. 600 and 300 B.c. This argument is that developed by D. M. Churchill who adduced other Fenland data conforming with this determination.

\section{Q-713. Hockwold, Norfolk}

$1464 \pm 154$

Decayed wood $\left(52^{\circ} 27^{\prime} 30^{\prime \prime} \mathrm{N}\right.$ Lat, $0^{\circ} 30^{\prime} \mathrm{E}$ Long) from Hockwold, a Roman settlement on the edge of the fens overlooking the Ouse River. A cesspit was part filled with chalky mud and clay and light sand on which rested pottery dated A.D. 190 to 250 . The pottery layer at $6 \mathrm{ft} 3 \mathrm{in}$. O.D. was overlain by silty chalk mud containing seeds and leaves of plants of wet swampy and waste ground; grey chalky silt extended to +8 ft O.D., where it was succeeded by the wood peat now sampled. Coll. P. Salway, Sidney Sussex College, Cambridge, 1962. $\delta \mathrm{C}^{13}-36.9 \%$. Comment: date agrees with that of the pottery. The deposits between the pottery and the dated wood peat were formed in fresh water which accumulatd as landward floods in the 3rd Century.

\section{Chapel Point, Lincolnshire series}

The exposition of the provenance and purpose of samples in the series was set out in Cambridge VI, p. 129.

\section{Q-685. Chapel Point, Lincolnshire, No. 1}

$3943 \pm 100$ 1993 B.c.

Peat $\left(53^{\circ} 14^{\prime} \mathrm{N}\right.$ Lat, $0^{\circ} 20^{\prime} 30^{\prime \prime} \mathrm{E}$ Long) from the contact of the lower peat with the overlying Triglochin (salt-marsh) clay at $-6 \mathrm{ft}$ O.D. Neolithic implements found by S. H. Warren appear to have been contemporaneous with this peat (Swinnerton, 1931). Pollen-analyses are referred to the (Fenland) Zone VIIb, equivalent to the lower peat in the southern Fenlands (Godwin, 1940). Smith (1958) referred the bed to the Bronze Age. Coll. D. M. Churchill. $\delta \mathrm{C}^{13}-31.0 \%$. Comment: on present information the radiocarbon date would fall within the Late-Neolithic rather than the Bronze Age, but the change from fresh water to marine conditions that it dates, corresponds with a change in the opposite sense (Fen Clay to Upper Peat) in the Cambridgeshire Fenland.

Q-844. Chapel Point, Lincolnshire, No. 5

$2815=100$

Phragmites peat $\left(53^{\circ} 14^{\prime} \mathrm{N}\right.$ Lat, $0^{\circ} 20^{\prime} 30^{\prime \prime} \mathrm{E}$ Long) grown in salt marsh from the top of the Upper Peat $(+5$ in O.D.) at the contact with the overlying Scrobicularia clay. Sample is from the same monolith as Q-686 which dated the base of the upper peat at $3340 \pm 110$ B.P. Coll. D. M. Churchill, Oct. 1961. $\delta \mathrm{C}^{13}-32.5 \%$. 
Comment on Chapel Point series: all dates from this site show a consistent time/depth sequence, as below:

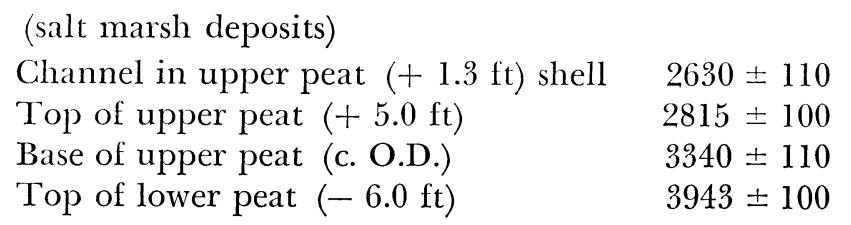

The upper peat at Ingoldmells on the same coast, dated $2455 \pm 110$ (Q-81) appears to be part of another intertidal marsh sequence. These results contradict the correlation suggested (Godwin, 1940) between these deposits and the peat/clay alternation in the southern Fenland basin.

\section{Fawley, Hampshire series}

In building a power station at Fawley, near Southampton on the $\mathrm{W}$ bank of the Solent $\left(50^{\circ} 49^{\prime} \mathrm{N}\right.$ Lat, $1^{\circ} 19^{\prime} 30^{\prime \prime} \mathrm{W}$ Long), a coffer dam was sunk into a sequence of estuarine clays and freshwater peat beds overlying sands and gravels stratified as follows: estuarine blue-grey clay with Scrobicularia plana and Hydrobia sp. from $-4 \mathrm{ft}$ to $-9 \mathrm{ft}$ O.D.; peat from $-9 \mathrm{ft}$ to $-14 \mathrm{ft}$ O.D. (samples Q-831, 832) ; blue-grey estuarine clay as above from $-14 \mathrm{ft}$ to $-23 \mathrm{ft}$ O.D.; sandy gravel. At one place only a small channel was cut into the surface of the gravel and then the above sequence continued downwards: blue-grey estuarine clay to $-23.5 \mathrm{ft}$; laminated silty Phragmites peat from $-23.5 \mathrm{ft}$ to $-24.5 \mathrm{ft}$ O.D. (sample Q-834); sand with pieces of drifted Quercus wood from $-24.5 \mathrm{ft}$ to $25 \mathrm{ft}$ O.D. (sample Q-835); gravel from $-25 \mathrm{ft}$ to at least $-35 \mathrm{ft}$ O.D. Coll. D. M. Churchill, July, 1964.

\section{Q-831. Fawley, Hampshire, No. 2}

$3689 \pm 120$

Phragmites peat from the top in. of peat below the contact with overlying estuarine clay at $-9 \mathrm{ft}$ O.D., Pollen-zone VIIa. Dates freshwater to estuarine transition. $\delta \mathrm{C}^{13}-33.0 \%$.

\section{Q-832. Fawley, Hampshire, No. 3}

$3563 \pm 96$

Betula wood under 2 in. diam from Betula-Phragmites fen-wood peat at $-13.5 \mathrm{ft}$ to $-14 \mathrm{ft}$ O.D., overlying khaki-coloured Phragmites clay which grades downward into soft blue-grey estuarine clay. Dates estuarine to freshwater transition. $\delta \mathrm{C}^{13}-30.5 \%$.

\section{Q-834. Fawley, Hampshire, No. 5}

$6366 \pm 124$

Silty Phragmites peat with fragments of charcoal at $-24 \mathrm{ft}$ O.D., the most peaty of a series of laminated peaty silty clays overlain by shingle at 
$-23 \mathrm{ft}$ O.D. at the base of the estuarine clay from which Q-832 was collected. Sample overlies sand and gravel, Pollen-zone VIIa. $\delta \mathrm{C}^{13}-31.5 \%$.

\section{Q-835. Fawley, Hampshire, No. 6}

$6318 \pm 134$

Quercus wood from sand overlying gravel at $-25 \mathrm{ft}$ O.D. in bottom of small channel from which Q-834 was taken $1 \mathrm{ft}$ higher. $\delta \mathrm{C}^{13}-32.5 \%$. Comment on Fawley series: whereas dates for Q-834 and Q-835 show the expected close agreement with one another, there is discordance between Q-831 with 3689 B.P. at the top of the peat bed and Q-832 with 3563 в.P. $5 \mathrm{ft}$ lower at its base: the peat bed may have formed quickly but it seems likely that one of the two dates is suspect. Churchill (1965) shows that relative to sites in Wales and SW England there must have been relative crustal downwarping of more than $10 \mathrm{ft}$ at Fawley since 6500 B.P.

\section{SW Scotland series}

In continuation of the series reported in Cambridge $\mathrm{V}$ (p. 59) we add new samples to supplement determination of the age of the " $25 \mathrm{ft}$ raised beach" of Northern Britain.

$$
3656=150
$$

Q-666. Heathershot, Bridge of Allan, Perthshire 1706 B.C.

Wood fragments and shells of Corylus $\left(56^{\circ} 8^{\prime} 30^{\prime \prime} \mathrm{N}\right.$ Lat, $3^{\circ} 58^{\prime} \mathrm{W}$ Long) from left bank of Teith R, $500 \mathrm{ft} \mathrm{NWN}$ of Heathershot, about $1.5 \mathrm{mi} \mathrm{W}$ of Bridge of Allan. Beneath ca. $10 \mathrm{ft}$ of beds taken to be "Carse Clays" is a layer $1.5 \mathrm{ft}$ thick of carbonaceous matter from which the sample was taken: this rested upon $1 \mathrm{ft}$ gravel over clay. Coll. B. M. Shipley, Macaulay Inst., Aberdeen, and W. A. Read, Geol. Survey, Edinburgh, 1961. Survey index No. U3895. $\delta \mathrm{C}^{13}-32.5 \%$.

\section{Q-667. Littleward, Kippen}

$3249 \pm 160$

1299 B.c.

Flattened wood $\left(56^{\circ} 9^{\prime} \mathrm{N}\right.$ Lat, $4^{\circ} 11^{\prime} \mathrm{W}$ Long) from left bank of Forth R, $1350 \mathrm{ft} \mathrm{E} 20^{\circ} \mathrm{S}$ of Littleward Wester, and immediately SE of Flanders Moss. Grid ref. NS 65499692, from immediately below beds taken to be "Carse Clays". Coll. B. M. Shipley and W. A. Read, 1961. Survey index No. U3896. $\delta \mathrm{C}^{13}-30.0 \%$.

Comment: these dates are far younger than any so far obtained for the peat/day contact below the Carse Clays, namely Q-421 Eastfield of Dunbarney, $8421 \pm 157$; Q-422 Broombarns, $8354 \pm 143$; Q-280 Airth Colliery, $8421 \pm 157$, dates supported by those beneath the " $25 \mathrm{ft}$ raised beach" in SW Scotland and N Ireland. Indeed the two dates now given are younger than samples dated from the upper surface of the Carse Clay at Flanders Moss which lies very closely adjacent (Q-533, $5492 \pm$ 130), and for one above the "25 ft raised beach" (Q-638, Lochar Moss, $6645 \pm 120)$. One would suspect that the "Carse Clays" from these latest samples are the result of a later phase of cutting and redeposition. 


\section{Archaeologic samples}

\section{Q-647. Abbott's track, Westhay Level, Somerset}

$4810 \pm 120$

2660 в.c.

Wood $\left(51^{\circ} 10^{\prime} \mathrm{N} \mathrm{Lat}, 2^{\circ} 50^{\prime} \mathrm{W}\right.$ Long) from prehistoric track known to extend for a considerable distance ca. $82^{\circ} \mathrm{W}$ of $\mathrm{N}$ from Westhay towards Catcott Burtle. First exposed in 1834, excavated and described in 1873 , it reappeared in fresh peat diggings in 1961. It has been carefully examined subsequently by Dr. J. M. Coles, Cambridge Univ. Dept. of Archaeol. and Anthropol. It lies close to the base of a thick layer of wellhumified Sphagnum-Calluna peat not far above a layer of wood peat that represents a vegetational transition from Cladium-Phragmites fen. This stratigraphic position strongly indicates a Neolithic age for the track which is unusually elaborate and massive for this period. Coll. H. Godwin, June 1961. Comment: date confirms the Neolithic age of the track and agrees closely with the radiocarbon age for two slighter tracks in the same locality and at the same stratigraphic level, Honeygore track, Q-431, $4750 \pm 130$; Honeycat track, Q-320, $4065 \pm 130 ;$ Q-427, $4326 \pm 130$; Q-429, 4215 \pm 130 (see Cambridge II; Godwin, 1960; Dewar \& Godwin, 1963).

$$
\begin{aligned}
& 3393 \pm 210 \\
& 1443 \text { B.c. } \\
& 3506 \pm 110 \\
& 1556 \text { B.c. }
\end{aligned}
$$

Q-837. North Ferriby, Yorkshire, No. 3

Wood ( $53^{\circ} 42^{\prime} 48^{\prime \prime} \mathrm{N}$ Lat, $0^{\circ} 29^{\prime} 52^{\prime \prime}$ E Long) from site on foreshore of $\mathrm{N}$ bank of Humber, a slat and tie found beneath one of two prehistoric 'sewn' boats excavated in 1941 (E. V. \& C. W. Wright, 1947). The slat and tie are artefacts and may be presumed to date the vessel. Coll. E. V. Wright, 1941; subm. D. M. Churchill, 1965. $\delta \mathrm{C}^{13}-32.5 \%$. Comment: the two independent assays agree but both are significantly older than BM-58 at $2700 \pm 150$ (British Museum II) which was from oak sealing strips found near the site of boats No. 1 and 2 but not collected until 1954; they are also older than Q-715 at $3120 \pm 105$ (Cambridge VII) for the wooden platform upon which rested remains of a third prehistoric boat of the same type and in the same stratigraphic situation. The wide spread of the dates is not understood although it covers the age expected on other grounds.

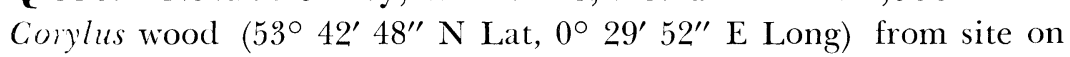
foreshore of $\mathrm{N}$ bank of Humber, a withe loop found projecting from surface of estuarine clay within $6 \mathrm{ft}$ of $\mathrm{E}$ end of prehistoric boat No. 3 and at same stratigraphic level as boat. Coll. E. V. Wright, 1963; subm. D. M. Churchill, 1965. $\delta \mathrm{C}^{13}-30.0 \%$. Comment: it was supposed that the wood was an artefact contemporary with the boats. Date appears to disprove this, but equally 12,950 в.P. is Late-Weichselian when Corylus avellana is unknown in Britain. 


\section{Q-764. Ashgrove Farm, Methilhill, Fifeshire 1000 B.c.}

Vegetable matter (56 $6^{\circ} 11^{\prime} 16^{\prime \prime} \mathrm{N}$ Lat, $3^{\circ} 2^{\prime} 38^{\prime \prime} \mathrm{W}$ Long) ca. $1 \mathrm{mi}$ inland from $\mathrm{N}$ shore of Firth of Forth, 11/4 mi NNW of Buckhaven (Grif ref. 352990). A mat of dicotyledonous leaf fragments, bark, twigs, charcoal and Sphagnum moss, ca. $1 \mathrm{ft}$ wide and 1 in. thick was found on the chest of a human skeleton in a cist grave, along with a late beaker and bronze dagger with horn hilt and bone pommel (Early Bronze Age) . Pollen analyses are remarkable for extremely high values of lime (Tilia cordata) not regarded as native in Scotland, and possibly due to flowering branches buried with the body, and of meadow sweet (Filipendula hexapetala), a strongly scented flower possibly also introduced in the same way. There are also clear indications of forest clearance. The burial corresponds with the first phase of the Wessex Culture in Southern England and hence the estimated age is 16 th century B.c. Coll. Prof. L. H. Butler, 1963; subm. Miss H. Henshall, Nat. Mus. Antiquities Scotland, Edinburgh. $\delta \mathrm{C}^{13}-36.0 \%$. Comment: radiocarbon age is unexpectedly late.

Q-814. Llanafan, Cardiganshire, No. 1

$2133 \pm 110$ 183 в.c.

Charcoal (52 $19^{\prime} \mathrm{N}$ Lat, $3^{\circ} 55^{\prime} \mathrm{W}$ Long), Nat. Grid Ref. SN 690711 from a layer in the $\mathrm{B}$ horizon of a soil of the Denbigh series, on a sloping hillside in Central Wales. The charcoal, 0.5 in. thick, is exposed for $3 \mathrm{ft}$ laterally, is overlain by $2 \mathrm{ft}$ of yellowish brown silt loam, and is apparently in situ above a thin burned layer (1.5 in.) above shattered shale a few inches thick over solid rock. Coll. C. C. Rudeforth, Soil Survey of England and Wales, 1962; subm. R. M. S. Perrin, Univ. School of Agriculture, Cambridge. Sample is intended to date the episode by which the top $2 \mathrm{ft}$ of mineral soil was deposited over the charcoal burnt-soil surface (Rudeforth, 1963). Some living rootlets and humus penetrated the charcoal layer, but these were as far as possible removed in pre-treatment of the sample. Comment: date agrees with the possibility that forest clearance and husbandry in the pre-Roman Iron Age induced erosion in this locality.

\section{ANTARGTICA}

Q-801. Signy Island, South Orkney Islands, No. 1 A.d. $1873 \pm 96$
Polytrichum-Dicranum moss $\left(60^{\circ} 40^{\prime}\right.$ S Lat, $45^{\circ} 40^{\prime}$ W Long $)$ from NW coast above Spindrift Rocks, between 150 and $200 \mathrm{ft}$ above sealevel. From one of the largest of the frozen banks of moss in the island, taken at the base, $5 \mathrm{ft}$ to $5 \mathrm{ft} 8 \mathrm{in}$. from the surface. About half the island is covered with permanent ice and snow and only two flowering plants are native to the island; the moss is living at the surface. Pollen analyses at 6 in. intervals through the bank have given substantial frequencies of different $S$. American plants from more than $500 \mathrm{mi}$ distance (D. M. Churchill anal.). Coll. M. Holdgate, Falkland Islands Dependencies Sur- 
vey, Feb. 1962. $\delta \mathrm{C}^{13}-27.5 \%$. Comment: date suggests a mean rate of growth of the moss bank ca. 1 in. in $30 \mathrm{yr}$ : the age calculation has assumed however the standard atmospheric activity.

Q-825. Signy Island, South Orkney Islands, No. $2 \Delta \mathbf{C}^{14}=+\mathbf{8 3 . 1 4}$

Drepanocladus-Polytrichum-Dicranum moss $\left(60^{\circ} 40^{\prime} \mathrm{S}\right.$ Lat, $45^{\circ} 40^{\prime} \mathrm{W}$ Long). Living moss from surface of moss bank, Hut Bank, $50 \mathrm{ft}$ above sealevel. Intended to provide a check on modern radiocarbon activity. Coll. M. Holdgate, British Antarctic Survey, Dec. 1963-Feb. 1964. Comment: result indicates an increase due to bomb carbon effect, probably diluted by an unknown amount of earlier moss in the sample which may represent 30 to 60 years growth.

JORDAN

\section{Q-729. Wadi Hasa, Terrace, III, No. 1}

$3950 \pm 150$

Charcoal $\left(30^{\circ} 51^{\prime} 15^{\prime \prime} \mathrm{N}\right.$ Lat, $35^{\circ} 55^{\prime} 15^{\prime \prime} \mathrm{E}$ Long) from upper Wadi Hasa, near Qa'lat el Hasa (Grid ref. 239028, sheet 2 of 1/250,000 map of Jordan, 1949). From a lens of charcoal $1 \mathrm{~m}$ below surface of Terrace III, the main valley floor which is in places $1 \mathrm{~km}$ wide and trenched by present-day stream. The terrace surface is underlain by fine, buff, wellbedded alluvium that contains artefacts identified by Dr. D. A. E. Garrod as Kebaran (Late Upper Palaeolithic), and is $4 \mathrm{~m}$ thick at the sampling point, resting directly on eroded bedrock (Vita-Finzi, 1964). Coll. C. VitaFinzi, St. John's College, Cambridge, 3 Jan. 1963 (see Vita-Finzi, 1963). Comment: carbon date shows that deposition which had begun in or after late Upper Palaeolithic times, continued into the 2nd millenium B.c.; it had ceased by the time classical pottery became available, although it was temporarily resumed in post-classical times to produce Terrace IV (C.V-F.) .

\section{NEW ZEALAND}

\section{Swampy Hill series, near Dunedin}

An extensive peat formation (blanket bog) covers the summit of Swampy Hill (45 $47^{\prime} 40^{\prime \prime} \mathrm{S}$ Lat, $170^{\circ} 28^{\prime} 45^{\prime \prime} \mathrm{E}$ Long), and at $\mathrm{N}$ end of this area, ESE of the Trig. point at $2433 \mathrm{ft}$ above sealevel a deep peat section was cut to the underlying basaltic surface. Pollen samples at $10 \mathrm{~cm}$ intervals and samples for radiocarbon dating were collected 11 Sept. 1963 by D. J. McIntyre and I. C. McKellar, New Zealand Geol. Survey. The site is probably equivalent to locality 4 of Cranwell and von Post (1936). Pollen analyses by D. J. McIntyre disclose an important sequence of vegetational changes which the radiocarbon samples are chosen to date. The diagram is divisible into three zones: I, 385 to $295 \mathrm{~cm}$ representing herbaceous and shrubby vegetation; II, 295 to $160 \mathrm{~cm}$, forest with Podocarpus spp (mainly $P$. ferrugineus type), Dacrydium bidwillii-biforme and Phyllocladus; III, 160 to $0 \mathrm{~cm}$, forest as before but supplemented by Dacrydium cupressinum, and Nothofagus spp in low frequency, Centrolepidaceae less abundant. 
Q-795. Swampy Hill, Dunedin (S 164/546)

$11,481 \pm 150$

9531 B.c.

Decomposed plastic reddish brown peat, $370 \mathrm{~cm}$ from surface just over contact with basaltic debris. Pollen spectrum notable for absence of trees and abundance of Coprosma, Ericales, Umbelliferae, Myrsine, Compositae, Gramineae, Cyperaceae and Centrolepidaceae: basal part of Zone I. $\delta \mathrm{C}^{12}-29.7 \%$.

\section{Q-796. Swampy Hill, Dunedin (S 164/547)}

$11,024 \pm 150$ 9074 B.c.

Decomposed plastic reddish brown peat, $300 \mathrm{~cm}$ from surface: upper part of Zone I immediately preceding great expansion of arboreal pollen, especially of Podocarpus spp. $\delta \mathrm{C}^{13}-34.0 \%$.

\section{Q-797 Swampy Hill, Dunedin (S 164/548)}

$7299 \pm 120$

Sinall lenses of fibrous plant material in decomposed plastic reddish brown peat, $200 \mathrm{~cm}$ from surface and two thirds up Zone II. $\delta \mathrm{C}^{13}-28.3 \%$.

\section{Q-798. Swampy Hill, Dunedin (S 164/549)}

$5427 \pm 110$

Fibrous root layer at top of decomposed plastic reddish brown peat, $100 \mathrm{~cm}$ from surface and one third up Zone III at level where substantial amounts of rimu (Dacrydium cupressinum) and small but consistent amounts of Nothofagus spp. occur. $\delta \mathrm{C}^{13}-27.1 \%$.

General comment on Swampy Hill series: $\mathrm{C}^{14}$ dates fix the occurrence of treeless vegetation type prior to 11,000 B.P. in SE South Island, New Zealand, a result consonant with the final retreat of the Otiran glaciers starting at ca. 14,000 to 15,000 B.P. The expansion of podocarp forest between 11,000 and say 10,000 B.P. in the broadest sense parallels forest expansion in $\mathrm{W}$ Europe after the Late-Weichselian. It is premature to attempt correlation of this vegetational phase or that which succeeds it until there are more numerous carbon-dated pollen sequences from other parts of New Zealand. Extrapolation of the time scale provided by the four dates indicates that from above the present surface a considerable depth of peat has been removed, probably by fire and erosion. This is important in any attempted correlation with accepted systems of zoning New Zealand pollen diagrams.

Date lists:

\section{REFERENCES}

British Museum II Barker and Mackey, 1960

Cambridge I $\quad$ Godwin and Willis, 1959

Cambridge II Godwin and Willis, 1960

Cambridge III Godwin and Willis, 1961

Cambridge V Godwin and Willis, 1962

Cambridge VI Godwin and Willis, 1964

Cambridge VII Godwin, Willis and Switsur, 1965

Barker, H. and Mackay, C. J., 1960, British Museum natural radiocarbon measurements II: Am. Jour. Sci. Radioc. Supp., v. 2, p. 26-30.

Birks, H. J. B., 1963-4, Chat Moss, Lancashire: Mem. \& Proc. Manchester Lit. and Phil. Soc., v. 106, p. 1. 
Churchill, D. M., 1965, The displacement of deposits formed at sea-level, 6,500 years ago in Southern Britain: Quaternaria VII, p. 239.

Cranwell, L. M. and von Post, L., 1936, Post-Pleistocene pollen diagrams from the southern hemisphere, I New Zealand: Geograf. Annaler, v. 3-4, p. 308.

Dewar, H. S. L. and Godwin, H., Archaeological discoveries in the raised bogs of the Somerset Levels, England: Prehist. Soc. Proc., v. 29, p. 17.

Godwin, H., 1940, Studies of the post-glacial history of British vegetation. III. Fenland Pollen diagrams; IV Post-glacial change of relative land- and sea-level in the English Fenland: Royal Soc. (London) Philos. Trans., ser. B., v. 230, p. 239. 1960, Prehistoric wooden trackways of the Somerset Levels: their construction, age and relation to climatic changes: Prehist. Soc. Proc., v. 26, p. 1.

Godwin, H., and Willis, E. H., 1959, Cambridge University natural radiocarbon measurements I: Am. Jour. Sci. Radioc. Supp., v. 1, p. 63-75.

1960, Cambridge University natural radiocarbon measurements II: Am. Jour. Sci. Radioc. Supp., v. 2, p. 62-72.

1961, Cambridge University natural radiocarbon measurements III: Radiocarbon, v. 3, p. 60-76.

1962, Cambridge University natural radiocarbon measurements V: Radiocarbon, v. 4 , p. $57-70$.

1964, Cambridge University natural radiocarbon measurements VI: Radiocarbon, v. 6, p. 116-137.

1965, Cambridge University natural radiocarbon measurements VII: Radiocarbon, v. 7, p. 205-212.

Phillips, C. W., 1936a, Roman Britain in 1935 in the Fens: Jour. Roman Studies, v. 26, p. 248 .

1936b, Notes and News: Antiquity, v. 10, p. 95.

Rudeforth, C. C., 1963, "Cardiganshire" in Report No. 16, Soil Survey of Great Britain. Smith, A. G., 1958, Post-glacial deposits in south Yorkshire and north Lincolnshire: New Phytologist, v. 57, p. 19.

Swinnerton, H. H., 1931, The post-glacial deposits of the Lincolnshire Coast: Q. J. Geol. Soc., v. 87 , p. 360.

Vita-Finzi, C., 1964, Observations on the Late Quaternary of Jordan: Palestine Expl. Q 96, p. 19.

Wright, E. V. and C. W., 1947, Prehistoric boats from North Ferriby, East Yorkshire: Proc. Prehist. Soc., N.S., v. 13, p. 114. 